\title{
Expression of Nerve Growth Factor, Brain-Derived Neurotrophic Factor and Neurotrophin-3 mRNAs in Human Cortical Xenografts
}

\author{
Christian Humpel $^{1,2}$, Ingrid Strömberg ${ }^{2}$ and Lars Olson ${ }^{2}$ \\ ${ }^{1}$ Neurochemistry Unit, Department of Psychiatry, Innsbruck, Austria \\ ${ }^{2}$ Department of Neuroscience, Karolinska Institute, Stockholm, Sweden
}

\begin{abstract}
SUMMARY
Trophic factors play an important role in the development of neurons and glia. In order to study the involvement of neurotrophins in human cortical development, human fetal parietal cortical tissue, obtained after early elective abortions, was transplanted to cortical cavities in immunosuppressed rats. Using in situ hybridization it was demonstrated that nerve growth factor, brain-derived neurotrophic factor and neurotrophin-3 mRNAs are expressed in developing human cortical xenografts. We conclude that neurotrophins may play a role in human cortical development and rat-derived astroglial cells could be involved in establishing reciprocal "permissive sites".
\end{abstract}

\section{KEY WORDS}

trophic factor, neurotrophins, transplant, permissive site, cortex, development

\section{INTRODUCTION}

To achieve a better understanding of the involvement of trophic factors in human cortical development, studies of the rodent cortex need to be supplemented with studies of the primate cortex. As an alternative to non-human primates, human-torat xenografts provide an interesting possibility $12,5,14,15,25,30,38-41 /$. The procurement of tissues after early elective routine abortions has

Reprint address:

Christian Humpel, Ph.D.

Neurochemistry Unit

Department of Psychiatry

Anichstr. 35

A-6020 Innsbruck, Austria permitted studies of human fetal CNS tissue grafted to immunocompromised rodent hosts and of the expression of different human genes and proteins. Growth factors play an important role in survival and differentiation in the CNS and the guiding/ targeting of nerve fiber growth. Nerve growth factor (NGF) and other neurotrophins, brainderived neurotrophic factor (BDNF), neurotrophin3 (NT-3) and neurotrophin-4/5, are all present in the brain, the highest levels of NGF, BDNF and NT-3 mRNAs being found in the hippocampus $/ 1,6,12,24,31,42 /$. Neurotrophins are also expressed in other brain areas, such as cerebral cortex, and may have important functional roles in this brain area, as shown in vitro and in vivo $/ 3,4,10,13,17,20$, $22,29,34,35 /$.

Recently, we demonstrated that human fetal cortical tissue fragments survive grafting to cavities of the rat brain $/ 16 /$. These tissue fragments became integrated with the host brain and formed reciprocal nerve fiber connections /16/. The ingrowth or outgrowth of nerve fibers seemed to occur at specific sites, so called 'permissive sites", probably guided by trophic interactions /16/. The human grafts significantly expressed angiotensinogen mRNA and protein, indicating a role for this neuropeptide precursor in cortical development $/ 18 /$. In a recent study we demonstrated BDNF mRNA in developing rat cortex, grafted in oculo to the anterior eye chamber $/ 17 /$. The aim of the present study was to observe whether the neurotrophin mRNAs (NGF, BDNF, NT-3) are expressed in developing human cortical xenografts. We showed that all three neurotrophins were found in these grafts and rat-derived astroglial cells could be involved in establishing reciprocal connections between graft and host. 


\section{MATERIALS AND METHODS}

\section{Grafting procedure}

Grafting was performed as described in detail previously $/ 16,18 /$. Human fetal parietal cortical fragments were recovered after first trimester (8.59.5 weeks) abortions. Women admitted for elective abortions, who had no prior knowledge of this study, were informed of the aims of the study and gave their consent. Anonymity was strictly maintained. The abortions were performed according to hospital routine, with low-pressure vacuum aspiration and with approval by the Regional Ethical Committee of the Karolinska Institute. A cavity in the cortex (bregma: -1 to -2 laterally) of halothane anesthetized female Sprague Dawley rats (B\&K Laboratories AB, Sweden, 200$220 \mathrm{~g}, \mathrm{n}=5$ ) was made by gentle suction with a modified glass pipette connected to an aspiration pump. The cavity was filled with gelfoam (Spongostan) soaked in Hanks' balanced salt solution (HBSS; Gibco). After 1-2 weeks, the gelfoam was removed under anesthesia to expose the cavity. Human cortical tissue pieces $\left(1-2 \mathrm{~mm}^{3}\right)$ were placed at the bottom of the cavity and the cavity closed with gelfoam soaked in HBSS. For immunosuppression all rats received daily injections of cyclosporine A (10 mg/kg; Sandoz) containing vibramycin ( $2 \mathrm{mg} / \mathrm{kg}$; Pfizer), starting the day before grafting. The total number of grafts studied was five.

\section{In situ hybridization}

At different times after grafting (16.5-34 weeks), animals were sacrificed, their brains removed, immediately frozen on dry ice, sectioned $(14 \mu \mathrm{m})$ with a cryostat (Leitz) and thawed onto slides (ProbeOn ${ }^{\mathrm{TM}}$ slides, Fisher Biotech, USA). In situ hybridization was performed as described previously $/ 19,44-46 /$. Oligonucleotides were labeled at the $3^{\prime}$ end with $\left[\alpha-{ }^{35}\right.$ S $]$ dATP using terminal deoxyribonucleotidyl transferase (NEN, DuPont, Sweden) and purified on nensorb columns (NEN). Sections were hybridized at $42^{\circ} \mathrm{C}$ overnight in a humidified chamber with $0.1 \mathrm{ml}$ per slide of the hybridization solution [ $50 \%$ formamide, $4 \mathrm{xSSC}$, $0.02 \%$ polyvinyl-pyrrolidone, $0.02 \%$ Ficoll, $0.02 \%$ bovine serum albumin, $10 \%$ dextrane sulfate, 0.5 $\mathrm{mg} / \mathrm{ml}$ sheared salmon sperm DNA, $1 \%$ sarcosyl (N-lauroyl sarcosine), $0.02 \mathrm{M} \mathrm{Na}_{3} \mathrm{PO}_{4}(\mathrm{pH} \mathrm{7.0),} 50$ $\mathrm{mM}$ dithiotreitol] containing $1 \times 10^{7} \mathrm{CPM} / \mathrm{ml}$ probe. Sections were subsequently rinsed, washed four times $\left(15 \mathrm{~min}\right.$ each) at $54^{\circ} \mathrm{C}$ in $1 \times \mathrm{xSC}$, cooled to room temperature, dehydrated through $70 \%, 90 \%$ and $99 \%$ ethanol and air dried. Sections were dipped in Kodak NTB-2 photo emulsion (diluted 1:1 in water), exposed for 6 (truncated trkB) and 15 weeks (neurotrophins) at $-20^{\circ} \mathrm{C}$, developed, fixed, and lightly counterstained with cresyl violet. Sections were analyzed using light and dark-field microscopy (Nikon Microphot) and photographed (Kodak Tmax-400). Slides were evaluated under the dark field microscope and the signal estimated using a semi-quantitative scale from 0-4.

The following antisense oligonucleotides were used:

NGF, bp 464-513 (5'-CCT GGG GTC CAC AGT AAT GTT GCG GGT CTG CCC CGC CAC GCG TGC AGC TAT) /43/; BDNF, bp 251-298 (5'-CTC CAG AGT CCC ATG GGT CCG CAC ACC TGG GTA GGC CAA GCT GCC TTG) /33/; NT-3, bp 379-429 (CTC CAA GGG GGT GCT GTC GCT CAG CAG GAC CCG CGG TGA ATT GTA GCG TCT) /26/; rat specific truncated trkB, bp 723-767 (5'-ACA TGG GGC AGG CAA GAG AAG CCC TCC AGA AGC CCA AGA CCA GCA) /27/.

\section{RESULTS}

All neurotrophin oligonucleotides showed cross reaction with rat and gave the expected hybridization signal in host rat hippocampus (Fig. 1, upper panel). NGF mRNA was strongly expressed in neurons in and around the host granule and pyramidal cell layer of hippocampus, BDNF mRNA was found in neurons in the granule and pyramidal cell layer of the hippocampal formation and NT-3 mRNA was seen in neurons of the granule cell layer of dentate gyrus and in CA2 and medial CA1 areas.

All three neurotrophins were expressed in the developing human cortical xenografts (Fig. 1, middle and lower panel). Clear scattered areas of NGF positive cells were detectable in the human transplants. The NGF mRNA signal was lowest in the younger grafts (16.5-20 weeks), reached a 

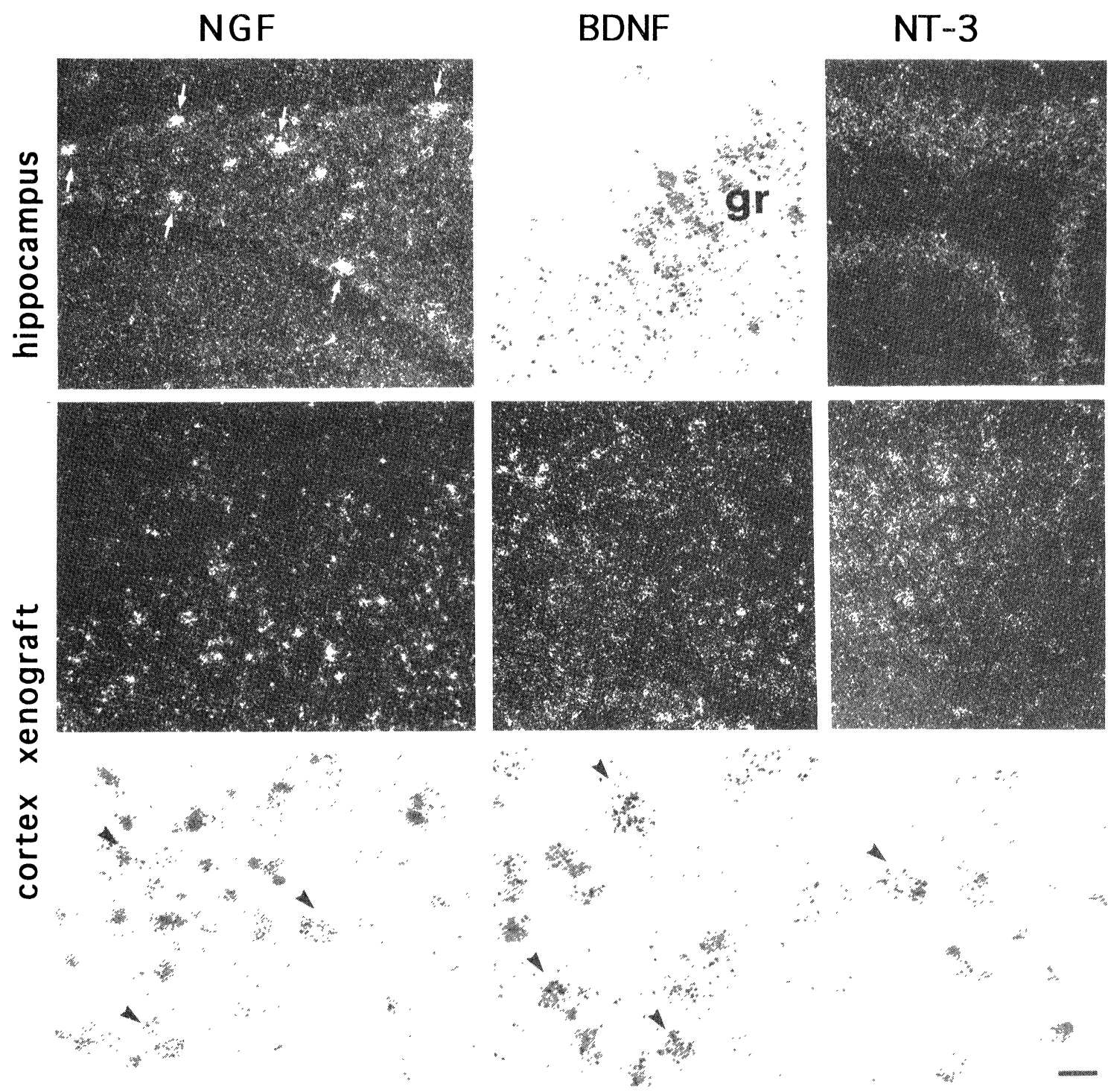

Fig. 1: Expression of neurotrophin mRNAs in dentate gyrus of the rat host hippocampus and in human cortical xenografts. The oligonucleotides cross react with rat and reveal NGF mRNA expression in neurons (arrows) inside the host granule cell layer of the dentate gyrus and in the hilus (left panel); BDNF mRNA expression in neurons in the granule (gr) cell layer of the hippocampal formation (middle panel), and NT-3 mRNA expression in neurons of the granule cell layer of dentate gyrus (right panel). In the human cortical xenografts clusters of cells were found expressing either NGF, BDNF or NT-3 mRNAs. The pictures show examples of transplants taken 25 (NGF and NT-3) or 16.5 (BDNF) weeks postgrafting. Bright field microscopy reveals specific localization of the silver grains over cresyl violet counterstained cells (lowest panel). Bar (from left to right) $=90,140,30 \mu \mathrm{m}$ (NGF); 20, 140, $20 \mu \mathrm{m}$ (BDNF); 70, 140, $25 \mu \mathrm{m}$ (NT-3).

maximum at week 25 , and decreased again in the older grafts (32-34 weeks) (Table 1). A strong patchy expression of BDNF mRNA was seen in the human cortical grafts. The signal for BDNF mRNA was highest in the youngest graft (16.5 weeks), slightly decreased thereafter, reaching a moderate expression in the older grafts (Table 1). NT-3
mRNA was found in the grafts in a patchy pattern. The signal for NT-3 mRNA peaked at week 25 (Table 1).

In situ hybridization for rat truncated trk $\mathrm{B}$ receptor mRNA showed a strong signal over the host cortex (Fig. 2a,b). The grafts partly revealed higher background but did not show a specific 


\section{TABLE 1}

Quantitative expression of nerve growth factor (NGF), brain-derived neurotrophic factor (BDNF) and neurotrophin-3 (NT-3) mRNAs in five different human cortical grafts, as evaluated by in situ hybridization

\begin{tabular}{llllll}
\hline graft & fetal age & grafts & \multicolumn{3}{l}{ mRNA expression in the grafts } \\
$\#$ & [weeks] & [weeks] & NGF & BDNF & NT-3 \\
\hline 1 & 9.5 & 16.5 & $+(+)$ & ++++ & + \\
2 & 9 & 20 & ++ & $+(+)$ & ++ \\
3 & 9.5 & 25 & $+++(+)$ & ++ & $+++(+)$ \\
4 & 8.5 & 32 & $+(+)$ & $+(+)$ & + \\
5 & 8.5 & 34 & $(+)$ & +++ & $+(+)$ \\
\hline
\end{tabular}

* The intensity of labeling was semiquantitatively graded: + low, ++ medium, +++ strong, and +++ very strong.
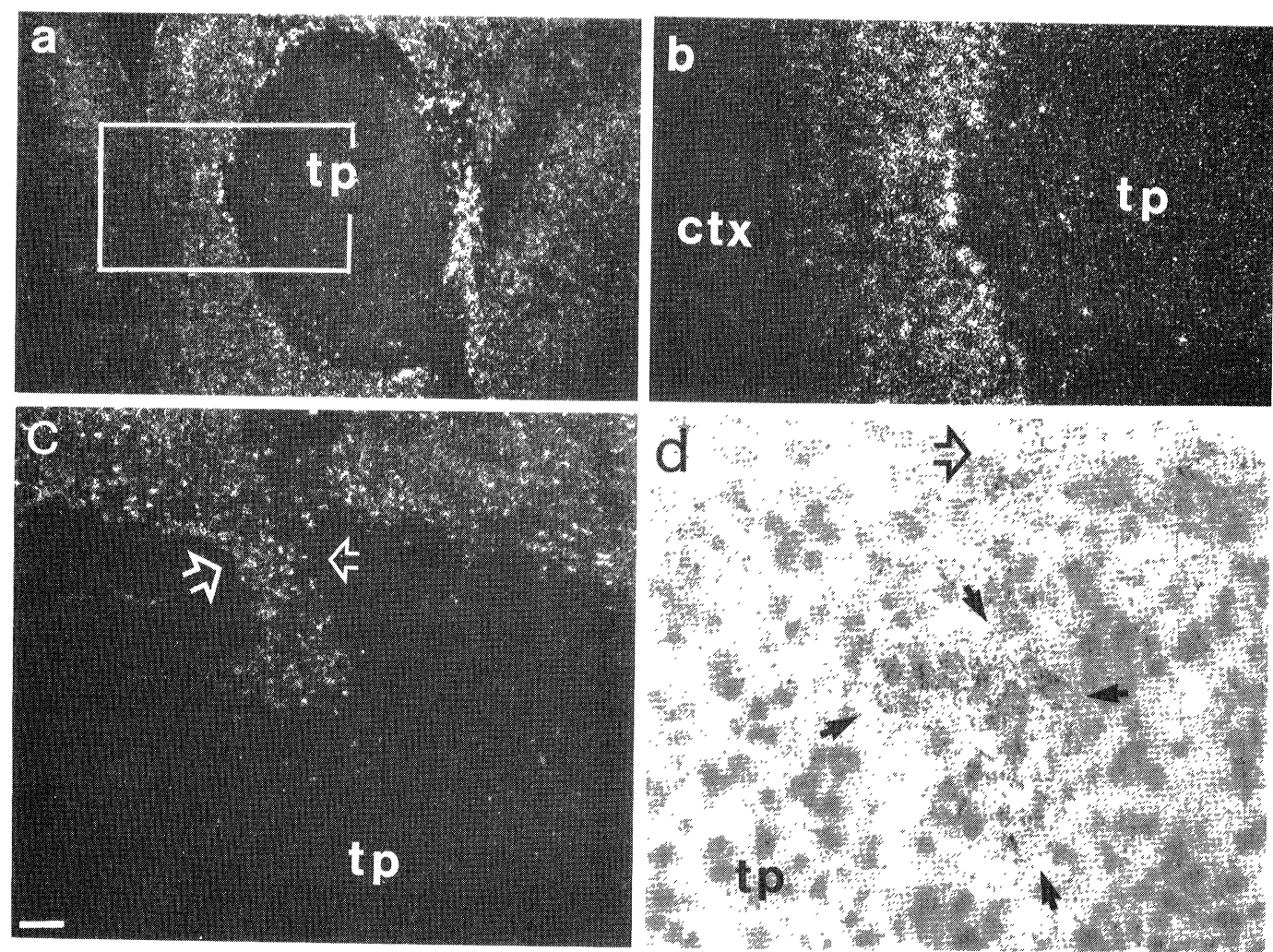

Fig. 2: High levels of expression of rat truncated trkB receptor mRNA are found in the rat host cortex (ctx), while the human transplants (tp) have a somewhat higher background but are negative $(a, b)$. Somewhat stronger signals are found close to the graft-host interface $(a, b)$. The box in Fig. a represents the area depicted at higher magnification in Fig. b. In a few areas a strong signal is found representing "permissive sites" (large arrows, c, d). Bright field microscopy reveals specific localization (small arrows) of silver grains over cresyl violet counterstained cells (d). Bar $=240 \mu \mathrm{m}(\mathrm{a}), 100 \mu \mathrm{m}$ (b), $150 \mu \mathrm{m}$ (c), $50 \mu \mathrm{m}$ (d). 
signal (Fig. 2a-d). Often the hybridization signal was increased at the graft-host interface (Fig. 2b). In a few cases a strong signal was found in ratderived cells, possibly in areas where nerve fibers entered the transplant (Fig. 2c,d).

\section{DISCUSSION}

This study is an extension of our previous studies in which human-to-rat cortical xenografts $/ 16,18 /$ and rat cortex in oculo grafts /17/ were characterized. Briefly, the majority of the grafts survived, became integrated with the rat host cortex and formed reciprocal nerve fiber connections. Specific "permissive sites" seem to be involved in this nerve fiber growth from graft to host and from host to graft. The present study demonstrates that NGF, BDNF and NT-3 mRNAs were expressed in the developing human cortical xenografts.

NGF, BDNF and NT-3 cross reacted with rat and gave the expected pattern of expression in the rat hippocampus $/ 9,12,31 /$. The probe for truncated trkB receptor gave strong signals all over the rat host brain, especially in rat cortex $/ 19 /$. The positive cells in the grafts expressing the neurotrophins and their receptors were identified using bright field microscopy, showing the silver grains to be located over cresyl violet counterstained cells.

Several studies have indicated a role for neurotrophins in cortical development in the rat. Using in situ hybridization, BNDF mRNA was found in several cortical areas (frontal, parietotemporal, cingulate and piriform) in the developing rat from 2 weeks of age and thereafter $/ 10 /$ and in prefrontal cortex of fetal and adult monkeys $/ 20 /$. Exogenous NGF affected the development of grafted cortex cerebri /8/ and BDNF, and much less potently NT-3, regulated neuropeptide expression in cultured cerebral cortical neurons $/ 29 /$. Castrén et al. $/ 3 /$ demonstrated that physiological stimuli (visual input changes) can regulate BDNF and trkB mRNAs in the visual cortex. Neurotrophins also seem to play an important role in glutamatemediated excitotoxicity in cortical neurons $/ 22,33$, 34/. Recently, we reported /17/ that BDNF mRNA as well as trkB receptor mRNAs were expressed in rat cortex cerebri grafted to the anterior chamber of the eye. BDNF mRNA expression was increased compared to adult cortices in single grafts and downregulated to near control levels by a compensating second graft, indicating trophic interactions $/ 17 /$. The present study extends these reports, and describes that all three analyzed neurotrophins, NGF, BDNF and NT-3, are expressed in the human cortical xenografts, likely playing important roles during development. Indeed, a recent report showed that BDNF is required for activity-dependent survival of cortical neurons $/ 13 /$. Since it was not easy to obtain several grafts of the same age in this study, the different age data need to be carefully interpreted. It might be possible that the different levels of mRNA expression do not represent normal developmentally regulated mRNA expression, but are merely a reflection of intra-transplantation or intra-donor variability.

Earlier studies of similar grafts suggested that most cells in our human grafts were immature /18/. Recently, we reported that the mRNA for a neuropeptide precursor, human angiotensinogen, was expressed mainly in immature protoplasmatic astrocytes in human cortical grafts $/ 18 /$. As we were not able to use non-radioactive in situ hybridization combined with glial immunomarkers, we cannot determine whether the neurotrophins are expressed in immature neurons and/or glial cells as well. However, since the localization of neurotrophins in glial cells has not been demonstrated by in situ hybridization in vivo, we suggest that the neurotrophin mRNAs are expressed in immature neurons in the human cortical grafts. This is in agreement with Miranda et al. $/ 28 /$, who reported that NGF and BDNF and more rarely NT-3 mRNAs were expressed in the developing rat cerebral cortex.

The neurotrophins bind with high affinity to receptors encoded by members of the trk family of proto-oncogenes $/ 6,7,32 /$. The $t r k$-related gene trk $\mathrm{B}$ encodes a high-affinity signal transducing component, having high affinity for both BDNF and NT-3 136,37/. The full-length trkB contains a tyrosine kinase domain, while truncated trkB lacks an intracellular signal-transducing domain $/ 21,27 /$. In the CNS, the full-length trkB mRNA is predominantly expressed in neurons, while expression of truncated trkB is predominantly found in glial cells $/ 11,21,44 /$. Miranda et al. $/ 28 /$ recently demon- 
strated that the trkB receptor $m R N A$ is expressed in the developing rat cerebral cortex, and is coexpressed with different neurotrophins. Kumar et al. $/ 23 /$ reported that $t r k \mathrm{~B}$ is present in astrocytes and upregulated by NGF, suggesting a role in normal glial function. In our study, truncated trkB mRNA expression was often very strong in areas at the graft-host interface to the cortical grafts indicating that rat astroglial processes are involved. We have also observed a similar phenomenon in intraoculo rat cortical transplants $/ 17 /$. The present data indicate that glial processes and the high affinity $t r k \mathrm{~B}$ receptor might be involved in neuronal and glial communication at the graft-host border.

"Permissive sites" seem to be responsible for establishing reciprocal nerve fiber connections. Several cases of such "permissive sites" were found in our human cortical grafts and nerve fibers labeled with human-specific neurofilament antibody entered such sites (for details see $/ 16,18 /$ ). We report now that these "permissive sites" appear to contain ratderived cells expressing the truncated trkB receptor mRNA. These cells seem to form an entry for the ingrowth (or outgrowth) or nerve fibers, starting from a specific point at the host-graft interface. We suggest that these cells are rat astrocytes, because truncated $\operatorname{trk} \mathrm{B}$ is predominantly found in glial cells and neurons, while the expression of full length $\operatorname{trk} \mathrm{B}$ is restricted to neurons. At the "permissive sites", it might be possible that astroglial processes are necessary for guiding/targeting nerve fiber growth and that neurotrophins could play a role in this process.

This study shows that mRNAs for NGF, BDNF and NT-3 are expressed in developing human cortical grafts. We conclude that neurotrophins may play a role during development and nerve fiber growth in the human cortex, and rat-derived astroglia could be involved in establishing reciprocal connections.

\section{ACKNOWLEDGEMENTS}

C.H. was supported by the Austrian Scientific Research Fund (J0567MED and J0756MED; Schrödingerstipendium). This study was supported by the Swedish Medical Research Council (14X03185 and 09917), the Marianne and Marcus
Wallenberg Foundation and the US Public Health Service (grants NS 09199 and AG 04418). We thank Susanne Almström, Eva Lindqvist, Karin Lundströmer and Monica Nyman for skillful technical assistance. We thank Cynthia Wetmore for designing the oligonucleotide probes.

\section{REFERENCES}

1. Barde YA. The nerve growth factor family. Prog Growth Factor Res 1990, 2: 237-248.

2. Blunt SB, Jenner P, Marsden CD. Autoradiographic study of striatal $D_{1}$-dopamine and $D_{2}$-dopamine receptors in 6-OHDA-lesioned rats receiving foetal ventral mesencephalic grafts and chronic treatment with L-DOPA and carbidopa. Brain Res 1992; 582: 299-311.

3. Castrén E, Zafra F, Thoenen H, Lindholm D. Light regulates expression of brain-derived neurotrophic factor messenger RNA in rat visual cortex. Proc Natl Acad Sci USA; 89: 9444-9448.

4. Ceccatelli S, Ernfors P, Villar MJ, Persson H, Hökfelt T. Expanded distribution of messenger RNA for nerve growth factor, brain-derived neurotrophic factor and neurotrophin-3 in the rat brain after colchicine treatment. Proc Natl Acad Sci USA 1991; 88: 1035210356.

5. Clarke DJ, Brundin P, Strecker RE, Nilsson OG, Björkland A, Lindvall $O$. Human fetal dopamine neurons grafted in a rat model of Parkinson's disease: ultrastructural evidence for synapse formation using tyrosine hydroxylase immunocytochemistry. Exp Brain Res 1988; 73: 115-126.

6. Ebendal T. Function and evolution in the NGF family and its receptors. J Neuroscience Res 1992; 32: 461470.

7. Eide FF, Lowenstein DH, Reichardt LF. Neurotrophins and their receptors: Current concepts and implications for neurologic disease. Exp Neurol 1993; 121: 200214.

8. Eriksdotter-Nilsson M, Skirboll S, Ebendal T, Olson $\mathrm{L}$. Nerve growth factor can influence growth of cortex cerebri and hippocampus: Evidence from intraocular grafts. Neuroscience 1989; 30: 755-766.

9. Ernfors P, Merlio JP, Persson H. Cells expressing messenger RNA for neurotrophins and their receptors during embryonic rat development. Eur $\mathrm{J}$ Neurosci 1992; 4: 1140-1158.

10. Friedman WJ, Olson L, Persson H. Cells that express brain-derived neurotrophic factor mRNA in the developing postnatal rat brain. Eur J Neurosci 1991; 3 : 688-697.

11. Frisen $J$, Verge $V$, Fried $K$, Risling $M$, Persson $H$, Trotter J, Hökfelt T, Lindholm D. Characterization of 
glial trkB receptors - differential response to injury in the central and peripheral nervous system. Proc Natl Acad Sci USA 1993; 90: 4971-4975.

12. Gall CM. Regulation of brain neurotrophin expression by physiological activity. Trends Pharmacol Sci 1992; 13: 401-403.

13. Ghosh A, Carnahan J, Greenberg ME. Requirement for BDNF in activity-dependent survival of cortical neurons. Science 1994; 263: 1618-1623.

14. Granholm AC, Eriksdotter-Nilsson M, Strömberg I, Stieg P, Seiger A, Bygdeman M, Geffard M, Oertel W, Dahl D, Olson L, Hoffer B, Freedman R. Morphological and electrophysiological studies of human hippocampal transplants in the anterior eye chamber of athymic nude rats. Exp Neurol 1989; 104: 162-171.

15. Granholm AC, Gerhardt GA, Bygdeman M, Strömberg I. Human fetal xenografts of brainstem tissue containing locus coeruleus neurons: functional and structural studies of intraocular grafts in athymic nude rats. Exp Neurol 1992; 118: 7-17.

16. Humpel C, Bygdeman M, Olson L, Strömberg I. Human fetal neocortical tissue grafted to rat brain cavities grows leads to reciprocal fiber connections and accumulates host IgG. J Comp Neurol 1994; 340: 337 348.

17. Humpel C, Giacobini MMJ, Wetmore C, Olson L. Brain-derived neurotrophic factor and trkB receptor mRNAs in grafts of cortex cerebri. Exp Neurol 1994; 127: 171-177

18. Humpel C, Lippoldt A, Strömberg I, Bygdeman M, Wagner J, Hilgenfeldt U, Ganten D, Fuxe K, Olson L. Human angiotensinogen is highly expressed in human cortical grafts. Glia 1994; 10: 186-192.

19. Humpel C, Wetmore C, Olson L. Regulation of brainderived neurotrophic factor messenger RNA and protein at the cellular level in pentylenetetrazolinduced epileptic seizures. Neuroscience 1993; 53 : 909-918.

20. Huntley GW, Benson DL, Jones EG, Isackson PJ. Developmental expression of brain derived neurotrophic factor mRNA by neurons of fetal and adult monkey prefrontal cortex. Dev Brain Res 1992; 70: 5363.

21. Klein R, Conway D, Parada LF, Barbacid M. The trkB tyrosine protein kinase gene codes for a second neurogenic receptor that lacks the catalytic kinase domain. Cell 1990; 61: 647-656.

22. Kokaia Z, Gidö G, Ringstedt T, Bengzon J, Kokaia M, Siesjö BK, Persson H, Lindvall O. Rapid increase of BDNF mRNA levels in cortical neurons following spreading depression: regulation by glutamatergic mechanisms independent of seizure activity. Mol Brain Res 1993; 19: 277-286.

23. Kumar S, Pena LA, Devellis J. CNS glial cells express neurotrophin receptors whose levels are regulated by NGF. Mol Brain Res 1993; 17: 163-168.
24. Levi-Montalcini R, Aloe L, Alleva E. A role for nerve growth factors in nervous endccrine and immune systems. Prog Neuroendocrinol 1990; 3: 1-10.

25. Mahalik TJ, Strömberg I, Gerhardt GA, Granholm AC, Seiger A, Bygdeman M, Olson L, Hoffer BJ, Finger T. Human ventral mesencephalic xenografts to the catecholamine-depleted striata of athymic rats: Ultrastructure and immunohistochemistry. Synapse 1989; 4: 19-29.

26. Maisonpierre PC, Belluscio L, Squinto S, Ip NY, Furth ME, Lindsay RM, Yancopoulos GD. Neurotrophin-3: a neurotrophic factor related to NGF and BDNF. Science 1990; 247: 1446-1451.

27. Middlemas DS, Lindberg RA, Hunter T. trkB a neural receptor protein-tyrosine kinase: evidence for a fulllength and two truncated receptors. Mol Cell Biol 1991; 11: 143-153.

28. Miranda RC, Sohrabji F, Toran-Allerand CD. Neuronal colocalization of mRNAs for neurotrophins and their receptors in the developing central nervous system suggests a potential for autocrine interactions. Proc Natl Acad Sci USA 1993; 90: 6439-6443.

29. Nawa H, Bessho Y, Carnahan J, Nakanishi S, Mizuno $\mathrm{K}$. Regulation of neuropeptide expression in cultured cerebral cortical neurons by brain-derived neurotrophic factor. J Neurochem 1993; 60: 772-775.

30. Olson L, Strömberg I, Bygdeman M, Granholm AC, Hoffer B, Freedman R, Seiger A. Human fetal tissues grafted to rodent hosts: structural and functional observations of brain adrenal and heart tissues in oculo. Exp Brain Res 1987; 67: 163-178.

31. Persson $H$, Ernfors $P$, Ibáñez C, Hallböök R, Friedman W, Merlio J, Lindvall O, Bengzon J, Lindefors N, Ebendal T, Olson L. Neurotrophins and their receptors. In: Gage F, Christen Y, eds. Gene Transfer and Therapy in the Nervous System. Berlin: SpringerVerlag, 1992: 180-200.

32. Raffioni S, Bradshaw RA, Buxser SE. The receptors for nerve growth factor and other neurotrophins. Ann Rev Biochem 1993; 62: 823-850.

33. Rosenthal A, Goeddel DV, Nguyen T, Martin E, Burton LE, Shih A, Laramee GR, Wurm F, Mason A, Nikolics K, Winslow JW. Primary structure and biological activity of human brain-derived neurotrophic factor. Endocrinology 1991; 129: 12891294.

34. Shimohama S, Tamura Y, Akaike A, Tsukahara T, Ohara $\mathrm{O}$, Watanabe S, Kimura J. Brain-derived neurotrophic factor pretreatment exerts a partially protective effect against glutamate-induced neurotoxicity in cultured rat cortical neurons. Neurosci Lett 1993; 164 : 55-58.

35. Shimohama S, Ogawa N, Tamura Y, Akaike A, Tsukahara $\mathrm{T}$, Iwata $\mathrm{H}$, Kimura J. Protective effect of nerve growth factor against glutamate-induced neurotoxicity in cultured cortical neurons. Brain Res 1993; 6.32: 296-302. 
36. Soppet D, Escandon E, Maragos J, Middlemas D, Reid S, Blair J, Burton L, Stanton B, Kaplan D, Hunter T, Nikolics K, Parada L. The neurotrophic factors brainderived neurotrophic factor and neurotrophin-3 are ligands for the trkB tyrosine kinase receptor. Cell 1991; 65: 895-903.

37. Squinto SP, Stitt TN, Aldrich TH, Davis S, Bianco SM, Radziejewski C, Glass DJ, Masiakowski P, Furth ME, Valenzuela DM, Distefano PS, Yancopoulos GD. trkB encodes a functional receptor for brain-derived neurotrophic factor and neurotrophin-3 but not nerve growth factor. Cell 1991; 65: 885-893.

38. Strömberg I, Bygdeman $M$, Goldstein $M$, Seiger A, Olson L. Human fetal substantia nigra grafted to the dopamine-denervated striatum of immunosuppressed rats: evidence for functional reinnervation. Neurosci Lett 1986; 71: 271-276.

39. Strömberg I, Almqvist $P$, Bygdeman $M$, Finger TE, Gerhardt G, Granholm AC, Mahalik TJ, Seiger A, Hoffer B, Olson L. Intracerebral xenografts of human mesencephalic tissue into athymic rats: Immunochemical and in vivo electrochemical studies. Proc Natl Acad Sci USA 1988; 85: 8331-8334.

40. Strömberg I, Almqvist P, Bygdeman M, Finger TE, Gerhardt G, Granholm AC, Mahalik TJ, Seiger A, Olson L, Hoffer B. Human fetal mesencephalic tissue grafted to dopamine-denervated striatum of athymic rats: Light- and electron-microscopical histochemistry and in vivo chronoamperometric studies. J Neurosci 1989; 9: 614-624.

41. Strömberg I, Bygdeman M, Almqvist P. Targetspecific outgrowth from human mesencephalic tissue grafted to cortex or ventricle of immunosuppressed rats. J Comp Neurol 1992; 315: 445-456.

42. Thoenen $H$. The changing scene of neurotrophic factors. Trends Neurosci 1991; 14: 165-170.

43. Ullrich A, Gray A, Berman C, Dull TJ. Human betanerve growth factor gene sequence highly homologous to that of mouse. Nature 1983; 303: 821-825.

44. Wetmore C. Brain-derived neurotrophic factor. Ph.D Thesis. Karolinska Institute, Stockholm, Sweden 1992.

45. Wetmore C, Ernfors P, Persson H, Olson L. Localization of brain-derived neurotrophic factor mRNA to neurons in the brain by in situ hybridization. Exp Neurol 1990; 109: 141-152.

46. Wetmore C, Olson L, Bean AJ. Regulation of brainderived neurotrophic factor (BDNF) expression and release from hippocampal neurons is mediated by nonNMDA type glutamate receptors. J Neurosci 1994; 14 : 1688-1700.

47. Wictorin K, Brundin $P$, Sauer $H$, Lindvall $O$, Björklund A. Long distance directed axonal growth from human dopaminergic mesencephalic neuroblasts implanted along the nigrostriatal pathway in 6hydroxydopamine lesioned adult rats. J Comp Neurol 1992; 323: 475-494. 

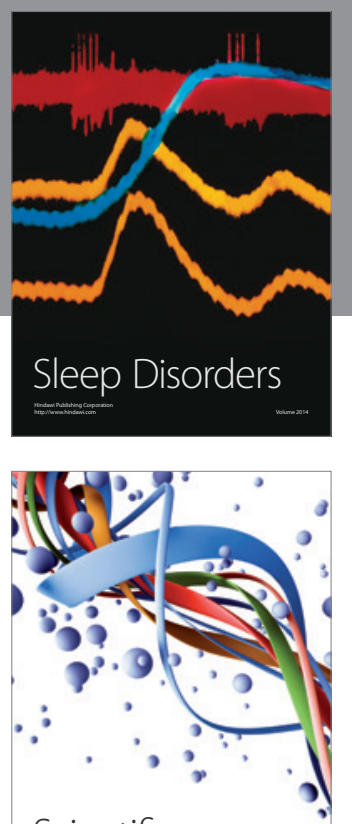

Scientifica
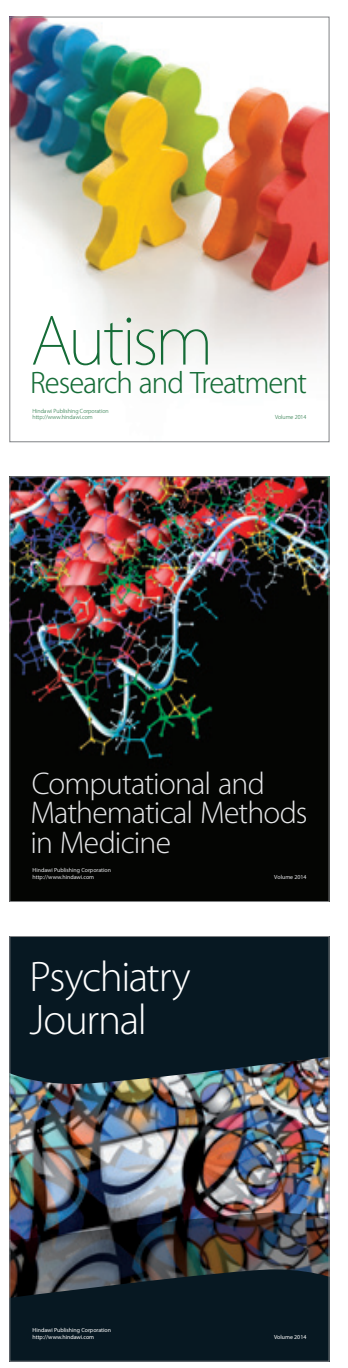
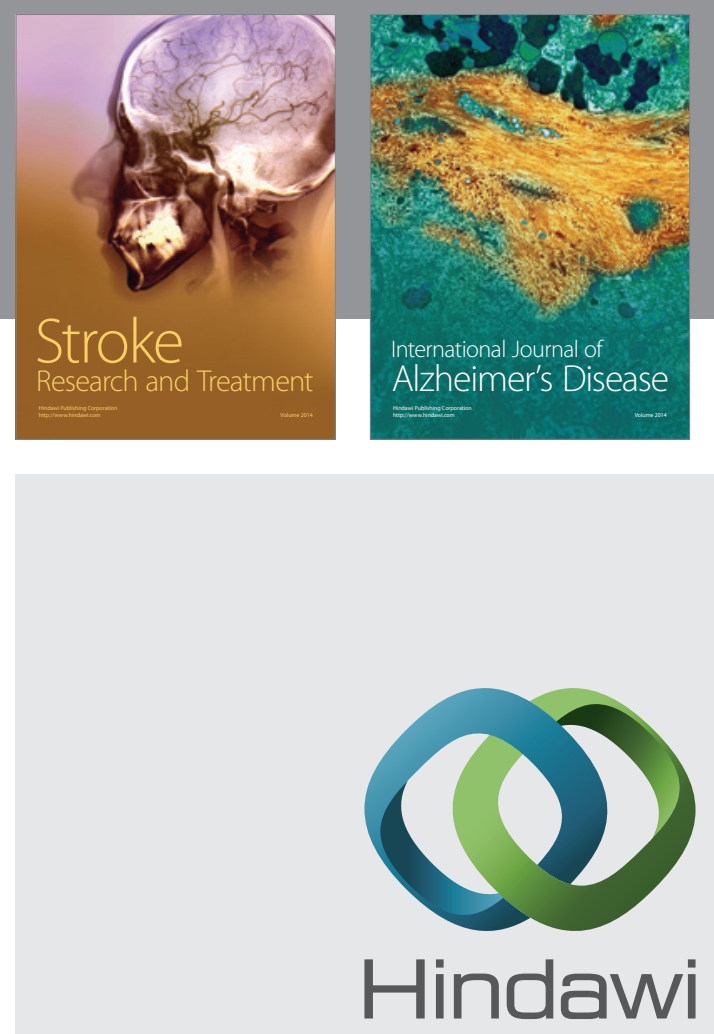

Submit your manuscripts at

http://www.hindawi.com
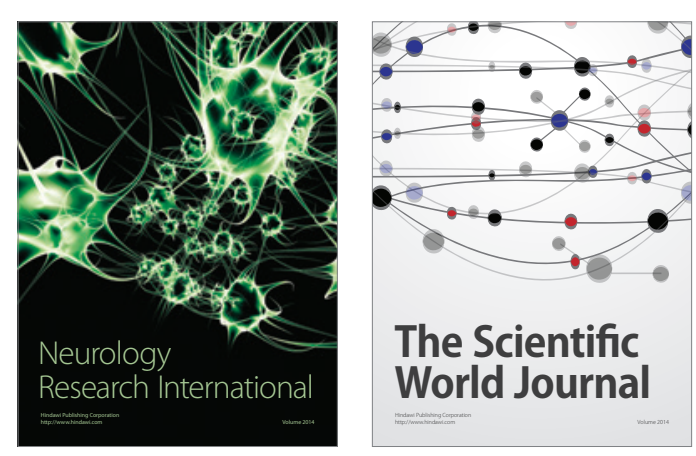

The Scientific World Journal

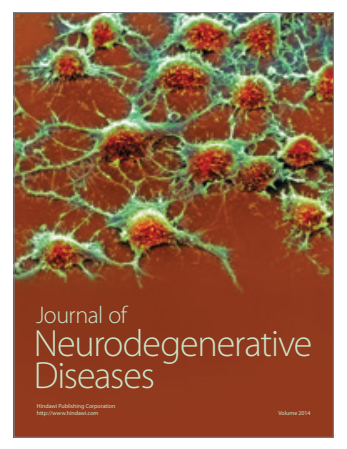

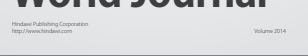

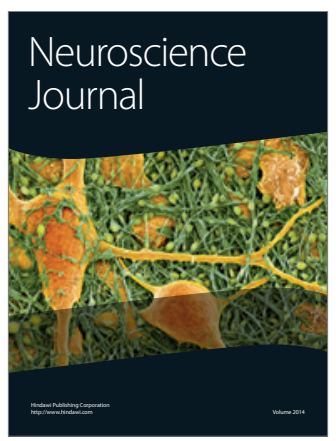

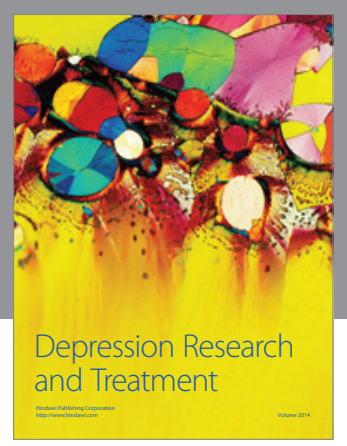
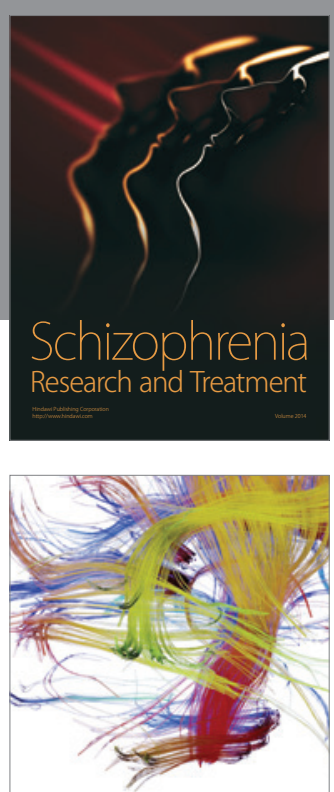

Brain Science

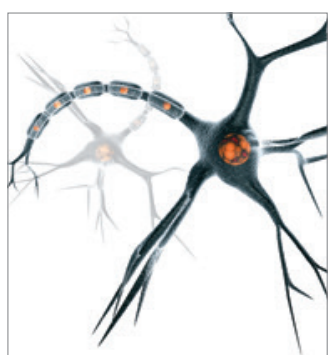

Neural Plasticity
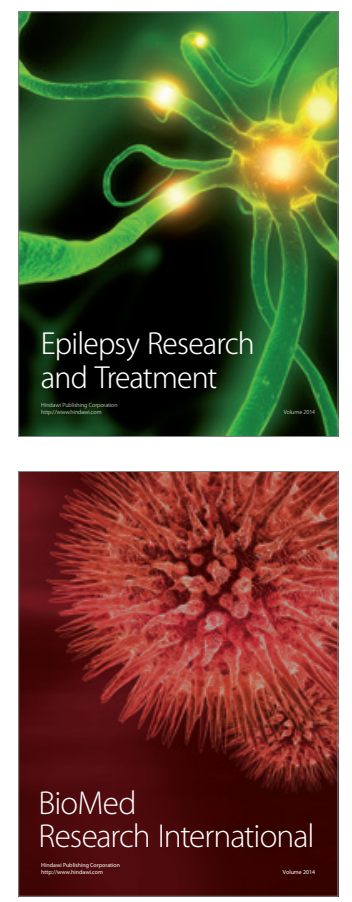

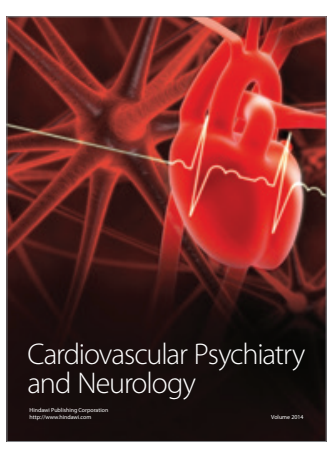

Parkinson's

Disease
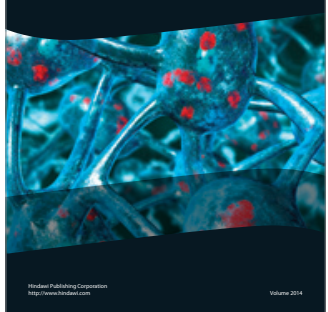